Człowiek chory i umierający. Możliwości wsparcia i formy pomocy, red. J. Stala, Kraków 2014, Wydawnictwo Naukowe UPJPII, s. 181-202. http://dx.doi.org/10.15633/9788374384117.13

Katarzyna Białożyt*

Uniwersytet Pedagogicznyw Krakowie

Agnieszka Haftek*

Akademia Ignatianum w Krakowie

\title{
CHOROBA TERMINALNA DZIECKA A FUNKCJONOWANIE RODZINY
}

Nieuleczalna choroba dziecka radykalnie wpływa na funkcjonowanie rodziny i zaburza jej harmonię. Rodzice i rodzeństwo nie będą w stanie żyć zupełnie normalnie, ponieważ sytuacja, w jakiej się znaleźli będzie wymagała od nich nieustannych poświęceń. Choremu dziecku trudniej niż dorosłemu znosić ból, ponieważ jest to dla niego zjawisko stosunkowo nowe i nieznane ${ }^{1}$. Bardzo istotną rolę w funkcjonowaniu rodziny może spełniać również najbliższe otoczenie, czyli dziadkowie, przyjaciele oraz wolontariusze, którzy są w stanie poprzez okazywane wsparcie i poświęcony czas realnie odciążyć rodziców i zapewnić poczucie bezpieczeństwa i akceptacji ${ }^{2}$.

\section{Zmaganie się dziecka $\mathrm{z}$ chorobą i cierpieniem}

Terminalna choroba dziecka zawsze związana jest z bólem i cierpieniem. Według Międzynarodowego Stowarzyszenia Badania Bólu ,jest to nieprzyjemne doznanie zmysłowe i emocjonalne związane $\mathrm{z}$ aktualnie występującym lub potencjalnym

* KATARZYNA BIAŁOŻYT - doktorantka Interdyscyplinarnych Studiów Doktoranckich w dziedzinie nauk społecznych na Uniwersytetu Pedagogicznego w Krakowie. Asystent w Katedrze Gerontologii Społecznej w Instytucie Pracy Socjalnej Uniwersytetu Pedagogicznego. Obszar zainteresowań i badań naukowych dotyczy głównie pracy socjalnej i gerontologii. Stypendystka Ministra Nauki i Szkolnictwa Wyższego (2012).

* AGNIESZKA HAFTEK - pracownik socjalny, pedagog, absolwentka Akademii Ignatianum w Krakowie.

1 Por. M. Białecka-Pikul, Dziecko chore $w$ domu. Rodzina w obliczu choroby dziecka, w: Śmierć dziecka a idea domowego hospicjum dla dzieci, red. M. Szczerbińska-Polak, Kraków 2005, s. 36-37.

2 Por. G. Nowicki, M. Czekała, Wolontariat w pediatrycznej opiece paliatywnej, w: Pediatryczna opieka paliatywna, red. A. Korzeniewska-Eksterowicz, W. Młynarski, Łódź 2011, s. 32-34. 
uszkodzeniem tkanek albo opisywane w kategoriach takiego uszkodzenia"3. Zgodnie $\mathrm{z}$ tą definicją ból jest zjawiskiem niezwykle trudnym do opisania, ponieważ zależy od subiektywnego odczucia pacjenta. Dorosły pacjent potrafi wyrazić słowami i gestami swoje odczucia, natomiast cierpienie u dzieci pozostaje „tajemnicą”. Można na podstawie ich opisów, gestów, wyrazu twarzy i zachowania rozpoznać ból i cierpienie, ale nie można dokładnie go określić. Pomimo, iż przeprowadzono niezliczoną ilość badań, nie sposób jest ustandaryzować i dokładnie określić, co czują mali pacjenci. Cierpienie dziecka można rozpatrywać w czterech aspektach: bólu fizycznego, cierpienia socjalnego, cierpienia emocjonalnego i cierpienia duchowego ${ }^{4}$.

Najbardziej widocznym w trakcie choroby terminalnej cierpieniem wydaje się ból fizyczny. Ból przewlekły, czyli trwający powyżej trzech miesięcy, towarzyszy praktycznie wszystkim nieuleczalnym chorobom. Związany jest zarówno z postępującym wyniszczeniem organizmu, jak i terapią mającą poprawić stan zdrowia. Badania wykazują, że ból u dzieci umierających na nowotwory jest znacznie ostrzejszy od bólu przy innych chorobach ${ }^{5}$. Dzieci nie potrafią zrozumieć sensu i znaczenia bólu, nawet, gdy towarzyszy on zabiegom mającym poprawić ich stan zdrowia. Ból kojarzy im się z karą za jakieś przewinienie, bądź też z innymi nieprzyjemnymi doznaniami. W przeciwieństwie do dorosłych mały pacjent bardziej boi się bólu fizycznego niż samej śmierci, ponieważ dla niego najważniejsza jest teraźniejszość, patrzy z zupełnie innej perspektywy niż dorosły. Dlatego nie zawsze potrafi zrozumieć decyzje rodziców, którzy zmuszają go do chemioterapii, radioterapii i innych zabiegów, które poprawiają jego stan fizyczny, ale powodują ból i cierpienie. Należy w tym miejscu powołać się na wyniki badania, które przeprowadzono wśród personelu pracującego w hospicjum dla dzieci i dorosłych. Ukazały one, iż ponad 94 proc. dzieci cierpi z powodu bólu fizycznego ${ }^{6}$. Nawet zaawansowana medycyna nie jest w stanie całkowicie pokonać największego źródła strachu, jakim jest obawa przed bólem fizycznym ${ }^{7}$.

Domowe hospicjum za jeden ze swoich podstawowych celów przyjmuje pomoc choremu dziecku. Ta pomoc sprowadza się głównie do uśmierzania bólu i cierpienia spowodowanego chorobą. Niestety, niektórym schorzeniom i kuracjom

\footnotetext{
3 J. Jarosz, M. Hilgier, Zasady diagnostyki i leczenia bólu, w: Podstawy opieki paliatywnej, red. K. de Walden-Gałuszko, Warszawa 2006, s. 20.

4 Por. D. Ryżanowska, Dziecko wobec cierpienia, w: Psychologia zdrowia dzieci i młodzieży, red. W. Pilecka, Kraków 2011, s. 244.

5 Por. P. S. Hinds, L. L. Oakes, J. Hicks, End-of-life care for children and adolescents, „Semin. Oncol. Nurs” 21 (2005) nr 1, s. 55.

6 Por. L. Kozłowska, K. Pietruk, Ból dziecka a ból osoby dorosłej. Postrzeganie bólu i cierpienia przez personel pracujący w hospicjum dla dzieci i dla dorosłych, w: W drodze do brzegu życia, tom VII, red. E. Krajewska-Kułak, C. Łukaszuk, Białystok 2009, s. 503.

7 Por. L. Kozłowska, K. Pietruk, Ból dziecka a ból osoby dorosłej..., dz. cyt., s. 503.
} 
leczniczym musi towarzyszyć ból fizyczny ${ }^{8}$. Dlatego bardzo ważna jest rozmowa z dzieckiem, aby mogło podzielić się swoimi odczuciami, aby mogło odczuć ulgę. Według niektórych badań dzieci odczuwają ból znacznie silniej niż dorośli, ponieważ jest to dla nich doznanie nowe, nieznane. Ich organizm nie jest przystosowany do znoszenia intensywnego i przewlekłego bólu. Dodatkowo, w większości chorób terminalnych cierpieniu towarzyszą inne objawy, takie jak osłabienie, apatia, krwawienia, duszności, wymioty, gorączka, kaszel, zaparcia, biegunka. Powoduje to znaczne osłabienie organizmu, co potęguje jeszcze uczucie bólu. Niezwykle ważne jest podawanie małym pacjentom odpowiednich lekarstw już z wyprzedzeniem, aby unikać sytuacji strachu i obawy przed cierpieniem. Strach ten jeszcze potęguje u nich doznania, co tworzy spiralę bólu. Ciekawym podejściem w pracy z dzieckiem jest też używanie kolorów do opisania natężenia bólu. Dziecko nie rozumie jeszcze dokładnie znaczenia intensywności i rodzaju cierpienia fizycznego, dlatego lekarz powinien w sposób zrozumiały dla małego pacjenta przekazywać mu informacje o bólu związanym $\mathrm{z}$ nadchodzącym zabiegiem czy leczeniem, ukazując mu go w postaci intensywnego koloru z przedstawionej wcześniej skali. Rodzice będą zawsze starali się walczyć o dobro dziecka, czasem zmuszając je do znoszenia bólu ponad jego siły w celu podjęcia kolejnej próby ratowania, ich zadaniem, jego życia. Specjalistyczny zespół domowego hospicjum ma za zadanie uświadomić rodzinie, że najważniejsze jest dobro dziecka i w niektórych przypadkach zadawanie cierpienia w celu podtrzymania nierealnych już marzeń rodziców przynosi tylko niepotrzebną udrękę?.

Od bólu fizycznego niejednokrotnie straszliwsze jest cierpienie emocjonalne. Dziecko bardzo boi się bólu fizycznego, ale w niektórych sytuacjach ten strach jeszcze potęguje bolesne doznania ${ }^{10}$. W wielu przypadkach dzieci dobrze rozumieją swoją chorobę, jej przyczynę, przebieg, zdają sobie sprawę z cierpienia i bólu, jakie będą musiały znosić. Natomiast rodzicom wydaje się, że unikając rozmowy na temat choroby, cierpienia, przyszłości i śmierci rozłożą nad nim „parasol ochronny". Taka postawa prowadzi do poddania się dziecka woli rodziców, bardzo często wbrew sobie i swoim pragnieniom. Unikanie rozmowy z dzieckiem na temat choroby, śmierci, powoduje, iż czuje się ono samotne, odtrącone. Nie zastanawia się nad sensem cierpienia i choroby, nie potrafi zrozumieć odtrącenia przez osoby mu

\footnotetext{
8 Por. R. Wójcik, Rodzaje bólu nowotworowego u dzieci, w: Leczenie bólu nowotworowego i opieka paliatywna nad dziećmi, red. T. Dangel, Warszawa 2001, s. 22.

9 Por. Ł. Przysło, Fenomenologia, neurobiologia, diagnostyka i leczenie bólu w pediatrii, w: Pediatryczna opieka paliatywna..., dz. cyt., s. 262-284.

${ }^{10}$ Por. H. Wrona-Polańska, Psychologiczne aspekty informowania pacjentów o chorobie, w: Zmagając się z choroba nowotworową. Psychologia współczesna wobec pacjentów onkologicznych, red. D. Kubacka-Jasiecka, W. Łosiak, Kraków 1999, s. 79-80.
} 
najbliższe ${ }^{11}$. Chore dziecko wymaga od rodziców otwartości, szczerego mówienia o ich uczuciach, problemach. Chce czuć się częścią systemu, jakim jest rodzina. Pomijanie go w ważnych decyzjach dotyczących jego samego, jego leczenia, może spowodować, iż będzie się czuło samotne. Samotność jest straszniejsza niż ból fizyczny. Przeprowadzony eksperyment Trevanthera ukazał, iż już w wieku niemowlęcym dziecko zaczyna rozumieć ignorowanie jego potrzeb i pragnień, potrafi reagować na brak zainteresowania ze strony matki odwróceniem się od niej ${ }^{12}$.

Poczucie osamotnienia może prowadzić do stanów lęku, depresji, która uniemożliwi dziecku przeżycie pozostałego mu czasu w sposób godny i szczęśliwy. W przeciwieństwie do dorosłych dziecko tak bardzo nie boi się śmierci, zależy mu na teraźniejszości. Poczucie bezpieczeństwa, które gwarantuje mu szczerości i bliskość kochających go ludzi jest dla niego najważniejsza i pomaga mu znosić cierpienie fizyczne ${ }^{13}$. W przeciwieństwie do dorosłych, dzieci nie czują gniewu spowodowanego chorobą, nie winią innych za swoje cierpienie. Jedynie zamknięta postawa rodziców, lekarzy czy najbliższych może wzbudzać w małym pacjencie poczucie winy. Obwinia siebie za to, że nie potrafi wyzdrowieć, że przysparza innym cierpienia, że nie jest wystarczająco silne, by znieść zabiegi mogące poprawić jego stan zdrowia. Dlatego zadaniem rodziców jest utwierdzanie chorego w przekonaniu, że nie jest winne niczemu, podkreślanie, jak bardzo są z niego dumni i doceniają jego walkę $\mathrm{z}$ chorobą ${ }^{14}$.

Wraz z bólem fizycznym i emocjonalnym może współwystąpić ból duchowy, który jest trudny do określenia. W zależności od wieku chorego i jego wychowania, potrafi odpowiednio zrozumieć znaczenie śmierci i miłości. Dla większości pacjentów śmierć oznacza zanik czynności biologicznych organizmu. Wraz z wiekiem zaczynają jednak rozumieć duchową istotę tego zjawiska. Jeżeli dziecko dorasta w rodzinie wierzącej, potrafi zrozumieć jej duchowy wymiar ${ }^{15}$. Dla niego śmierć jest tylko przejściem do lepszego świata, bez lęku i cierpienia. Jest nieunikniona, ale nie czuje przed nią strachu. Strach powoduje świadomość rozstania z ukochanymi osobami, ze światem ${ }^{16}$. W wymiarze religijnym czas umierania jest czasem ewangelizacji poprzez okazywanie miłości, poprzez modlitwę i udzielane sakramenty. Rodzi nadzieje

\footnotetext{
${ }^{11}$ Por. H. Wrona-Polańska, Psychologiczne aspekty informowania pacjentów o chorobie..., dz. cyt., s. 79-80.

12 Por. H. Olechnowicz, Dziecko własnym terapeuta, Warszawa 2006, s. 24-25.

${ }^{13}$ Por. K. de Walden-Gałuszko, Psychospołeczne aspekty opieki paliatywnej, w: Podstawy opieki paliatyw$n e j . . .$, dz. cyt., s. $167-171$.

${ }^{14}$ Por. J. Aldridge, Jak żyć z poważnie chorym dzieckiem, Kraków 2008, s. 35-39.

15 Por. R. Biniak, Opieka duchowna nad umierającymi, w: Opieka Paliatywna, red. M. Krajnik, M. Rogiewicz, Bydgoszcz 1998, s. 174-177.

${ }^{16}$ Por. C. Saunders, Hospicjum Św. Krzysztofa, w: Sens choroby, sens śmierci, sens życia, red. H. Bortnowska, Kraków 1980, s. 266-296.
} 
na spędzenie godnie reszty życia, na godną śmierć i życie wieczne ${ }^{17}$. Ta pomoc sprawia, że dziecko czuje się bezpieczne, kochane, że niezależnie od tego, ile mu dni jeszcze zostało, potrafi cieszyć się nimi. Doświadczenia księży wykazały, iż dziecko nie poszukuje sensu życia, nie stara się rozwiązać konfliktów w swoim sumieniu. Ono „intuicyjnie doświadcza miłości Boga"18. Dlatego należy zapewnić choremu dostęp do sakramentów, równocześnie wzmacniając jego odczucie śmierci, jako przejścia do lepszego życia zgodnie ze słowami Ojca Świętego Jana Pawła II. „Śmierć jest «wyjściem», po którym będziemy mogli oglądać oblicze Boga - źródło życia i miłości, tak jak dziecko, które po przyjściu na świat może oglądać twarze swoich rodziców. Dlatego Kościół mówi o śmierci, jako o drugich narodzinach"19.

Cierpienie socjalne dziecka związane jest $\mathrm{z}$ utraconą szansą na normalne funkcjonowanie w społeczeństwie. Pacjenci domowego hospicjum, niezależnie od stadium swojej choroby, nigdy nie będą mogli przeżyć beztrosko i radośnie swojego dzieciństwa, tak jak ich rówieśnicy. Ograniczenia motoryczne, trudności z oddychaniem, niepoprawne funkcjonowanie wielu narządów, upośledzenie umysłowe i wiele innych schorzeń uniemożliwiają choremu pacjentowi zabawę z rówieśnikami. Jest to przykre doznanie dla dziecka, które w ten sposób traci szanse na normalne dzieciństwo. Trudności z przystosowaniem się do otoczenia, poczucie wstydu spowodowane swoją chorobą, brak akceptacji ze strony innych są jednym z najstraszliwszych odczuć. Obok miłości ze strony rodziny, chore dziecko potrzebuje akceptacji i wsparcia ze strony innych ludzi, szczególnie tych najmłodszych. Jej brak może prowadzić do stanów osamotnienia, lęku, a nawet depresji, co wpływa na determinację $\mathrm{w}$ walce $\mathrm{z}$ chorobą ${ }^{20}$.

Janusz Korczak pisał, że „[...] dziecko ma słuszne prawa do ruchu, zabawy i zrozumiałej dla siebie sprawiedliwości" ${ }^{21}$. Godne przeżycie życia przez dziecko to okazywanie mu miłości, sprawienie, aby czuło się kochane, nie czuło bólu i cierpienia oraz mogło się bawić i uczyć odpowiednio do swoich możliwości fizycznych i intelektualnych. Podopieczny domowego hospicjum nie może uczęszczać do szkoły, nie może przebywać z innymi uczniami, dlatego czuje się bardzo często osobą gorszą od

\footnotetext{
${ }^{17}$ Por. J. Salij, Człowiek umierający jako bliźni, w: Sztuka rozmowy z chorym, red. B. de Barbaro, Kraków 2001, s. 113-122.

${ }^{18}$ L. Szczepaniak, Wybrane problemy opieki paliatywnej nad dzieckiem, w: Śmierć dziecka a idea domowego hospicjum..., dz. cyt., s. 23.

${ }^{19}$ Jan Paweł II, Chorzy na raka wołaja o pomoc. Przemówienie do Międzynarodowego Towarzystwa Onkologii Ginekologicznej z dnia 30 września 1999r., s. 43.

${ }^{20}$ Por. M. Białecka-Pikul, Dziecko chore $w$ domu. Rodzina w obliczu choroby dziecka, w: Śmierć dziecka a idea domowego hospicjum..., dz. cyt., s. 36-37.

${ }^{21}$ Myśli Korczaka, http://2012korczak.pl/ (o1.05.2013).
} 
innych. Niezwykle ważny jest więc kontakt z rodzeństwem, innymi dziećmi i wolontariuszami, którzy poprzez wspólną zabawę pokonują cierpienie socjalne ${ }^{22}$.

Wszystkie aspekty cierpienia, z jakimi musi radzić sobie pacjent domowego hospicjum i jego rodzina, powodują, iż życie dziecka nigdy nie będzie tak beztroskie i radosne jak jego rówieśników. Ból fizyczny i strach przed nim, poczucie osamotnienia społecznego, niedostatek miłości najbliższych czy ograniczenia ruchowe i umysłowe bardzo często towarzyszą mu w jego krótkim życiü ${ }^{23}$. Jednak miłość rodziców i najbliższych, wsparcie zespołu domowego hospicjum, wolontariuszy, nauczycieli i innych dzieci, przystosowanie się do nowych okoliczności, które stwarza choroba może sprawić, że na jego twarzy niejeden raz zagości spokój i uśmiech ${ }^{24}$.

\section{Akceptacja chorego dziecka przez najbliższe otoczenie i jej uwarunkowania}

Znoszenie bólu i cierpienia towarzyszącego chorobie w dużej mierze zależy od otoczenia dziecka. Ból fizyczny można zneutralizować odpowiednimi zabiegami medycznymi, jednak cierpienie emocjonalne dla dziecka jest o wiele straszniejsze. Bardziej niż dorośli, mały pacjent odczuwa potrzebę miłości, wsparcia, akceptacji ze strony otoczenia. Dla terminalnie chorego dziecka otoczeniem są rodzice, rodzeństwo, najbliższa rodzina, zespół domowego hospicjum, wolontariusze, a także rówieśnicy. Każdy z nich ma znaczący wpływ na zdrowie psychiczne dziecka, ale i od każdego z nich mały pacjent oczekuje innego rodzaju pomocy i wsparcia ${ }^{25}$.

W życiu każdego dziecka największe znaczenie ma postawa rodziców. Z nimi jest najbardziej związane emocjonalnie. To oni, jako pierwsi, pomagają mu poznać otaczający go świat. Pojawienie się wiadomości o śmiertelnej chorobie potomka powoduje $\mathrm{w}$ rodzinie skrajne emocje. Choroba dziecka, bezbronnego i niewinnego, nie może być wytłumaczona. Pytanie „dlaczego?” jest jednym z najczęściej stawianych pytań, ale żaden człowiek nie może na nie udzielić prawidłowej odpowiedzi ${ }^{26}$.

\footnotetext{
${ }^{22}$ Por. J. Aldridge, Jak żyć z poważnie chorym..., dz. cyt., s. 22-28.

${ }^{23}$ Por. M. Białecka-Pikul, Dziecko chore w domu. Rodzina w obliczu choroby dziecka, w: Śmierć dziecka a idea domowego hospicjum..., dz. cyt., s. 36-37.

${ }^{24}$ Por. B. Tobiasz-Adamczyk, K. Szafraniec, J. Bajka, Zachowania w chorobie. Opis przebiegu choroby z perspektywy pacjenta, Kraków 1999, s. 43.

${ }^{25}$ Por. M. Białecka-Pikul, Dziecko chore $w$ domu. Rodzina w obliczu choroby dziecka, w: Śmierć dziecka a idea domowego hospicjum..., dz. cyt., s. 38 .

${ }^{26}$ Por. M. Świderska, Pomoc świadczona rodzinie wychowującej dziecko niepetnosprawne, „Pedagogika rodziny" (2011) $\mathrm{nr} 1(2)$, s. 37-39.
} 
W literaturze wyróżnia się kilka okresów, przez które przechodzą rodzice, po otrzymaniu wiadomości o nieuleczalnej chorobie:

1. Pierwszym okresem po otrzymaniu informacji o nieuleczalnej chorobie, jest okres szoku, który charakteryzuje się gniewem, złością, załamaniem, rodzice popadają $\mathrm{w}$ rozpacz, ich plany i marzenia związane $\mathrm{z}$ dzieckiem nie będą nigdy zrealizowane. Na tym etapie życia rodzina nie może konstruktywnie działać, nie może nawet podejmować ważnych decyzji, ponieważ wszystkie będą powodowane wyłącznie emocjami i nie poprawią życia małego pacjenta hospicjum.

2. W kolejnym okresie rodzice przeżywają kryzys emocjonalny, żal i rozpacz często towarzyszy rodzinie w tym czasie. Bez odpowiedniej pomocy ze strony najbliższych i specjalistów rodzina może ulec rozpadowi, ponieważ jej członkowie mogą nie poradzić sobie z obciążeniem psychicznym, jakim jest terminalna choroba.

3. Okres pozornego przystosowania się, który następuje po kryzysie emocjonalnym, objawia się szukaniem winnych bądź obwinianiem się samemu, ponieważ dorośli, w przeciwieństwie do dzieci, odbierają chorobę jako karę. Pozorne przystosowanie oznacza próbę leczenia dziecka i niedopuszczanie do siebie informacji, iż choroba jest nieuleczalna.

4. Najważniejszym etapem, który musi osiągnąć rodzina, jest okres konstruktywnego przystosowania się do sytuacji. Rodzice potrafią zaakceptować swoje chore dziecko, rozumieją, że ich najważniejszym zadaniem nie jest już próba ratowania dziecka, szukania winnych ani użalania się nad sobą, ale skupienie się na umożliwieniu swojemu potomkowi przeżycia pozostałych mu chwil w sposób godny, obdarzając go miłością i zrozumieniem²7.

Rozwój systemu rodzinnego jest możliwy, dzięki przechodzeniu przez kolejne naturalne kryzysy rozwojowe, czyli funkcjonowanie w powtarzających się cyklach dostosowania, kryzysu i adaptacji ${ }^{28}$. W rodzinie, która zaakceptuje już swoją sytuację, chore dziecko obdarzone jest przede wszystkim miłością, która pomaga mu dzielnie walczyć z bólem i cierpieniem, nieuniknionymi przymiotami nieuleczalnych chorób. Rodzice wspierają go i cieszą się z każdego, nawet najdrobniejszego wysiłku, ponieważ jeden mały krok, każdy drobny sukces dla niego znaczy bardzo wiele i jest motywacją do życia i dalszego działania. Ważne jest też, aby w miarę możliwości umysłowych dziecka umożliwić mu podejmowanie własnych decyzji.

\footnotetext{
${ }_{27}$ Por. M. Świderska, Pomoc świadczona rodzinie wychowującej dziecko niepełnosprawne..., dz. cyt., s. 37-39.

${ }^{28}$ Por. M. Kuleta, Doświadczanie żalu po stracie w perspektywie społeczno-kulturowej. Znaczenie rytuałów żałobnych, w: Zdrowie, stres, choroba w wymiarze psychologicznym, red. H. Wrona-Polańska, Kraków 2008, s. 389-398.
} 
Konieczna jest ochrona dziecka przed niebezpieczeństwem, jednak niezwykle istotne jest jego poczucie wolności, możliwość kierowania własnym życiem ${ }^{29}$.

Gdy rodzice pogodzą się z terminalną chorobą, bardzo ważne jest okazanie tego swojemu dziecku. Akceptacja chorego polega w głównej mierze na zaakceptowaniu go, takim, jakim jest ${ }^{30}$. Pomimo niespełnionych marzeń związanych z jego przyszłością, pomimo bólu i cierpienia, jakie towarzyszyć mu będzie przez całe jego życie, konieczne jest umożliwienie mu przeżycia pozostałych chwil w zgodzie z jego naturą, z jego ograniczeniami fizycznymi i psychicznymi. Podstawą do tego jest szczera rozmowa, otwarte okazanie przez rodziców swoich niepokoi, aby dziecko wraz z nimi mogło wspólnie tworzyć swoją własną historię. Podstawowym błędem rodziców jest unikanie rozmowy o chorobie, o dręczących ich wątpliwościach, w celu, jak twierdzą, oszczędzenia dziecku stresu i cierpienia. Niestety, taka postawa osłabia więzy rodzinne, wzbudza w potomku poczucie niezrozumienia i odrzucenia. Mali pacjenci hospicjum bardzo często rozumieją przyczynę i zdają sobie sprawę z przebiegu swojej choroby, dlatego unikanie rozmów na jej temat i własnych emocji ze strony rodziców nie można nazwać akceptacją ${ }^{31}$.

Akceptacja dziecka polega na wspieraniu go w chorobie, w codziennej walce o najdrobniejsze nawet sukcesy, pomimo niesprzyjających okoliczności, pomimo cierpienia. Niezwykle ważna jest też umiejętność zaspokajania własnych potrzeb przez rodziców. Pełne zaakceptowanie chorego potomka wiąże się ze świadomością, że kiedyś odejdzie. Może przeżyć kilka miesięcy, a mogą minąć długie lata. Skupienie całej swojej uwagi na nim i poświęcenie mu każdej wolnej chwili sprawia, że rodzic może być w jego oczach odbierany jako „męczennik”, który zrezygnował ze wszystkiego dla jego dobra $^{32}$. Taka postawa rodzica, choć mogłaby się wydawać naturalna, może powodować u dziecka poczucie winy. Obwinia się za to, że jego choroba, on sam, zabiera swoim rodzicom szanse na normalne życie, nawet na chwile radości. Rodzice chcą być pewni, że z chwilą, gdy dziecko odejdzie, będą mogli powiedzieć, że zrobili dla niego wszystko, co było możliwe. Ale chory nie oczekuje całodobowej uwagi, podobnie jak jego zdrowi rówieśnicy. Chce przede wszystkim czuć się kochane, czuć, że może w każdej chwili liczyć na pomoc rodziców. Pełna akceptacja polega więc nie na poświęceniu mu całego swojego czasu, kosztem rezygnacji ze swojego życia, ale na wspieraniu go w chorobie i okazywaniu mu swojej miłości, bo to jest dla niego najważniejsze ${ }^{33}$.

\footnotetext{
${ }^{29}$ Por. M. Kuleta, Doświadczanie żalu po stracie w perspektywie społeczno-kulturowej..., dz. cyt., s. 389-398.

${ }^{30}$ Por. Z. Dąbrowski, Pedagogika opiekuńcza w zarysie, Olsztyn 2006, s. 219-220.

${ }^{31}$ Por. B. Tryjarska, Systemowa - komunikacyjna terapia rodzin, w: Psychoterapia. Praktyka-podręcznik akademicki, red. L. Grzesiuk, Warszawa 2006, s. 114.

${ }^{32}$ Por. J. Aldridge, Jak żyć z poważnie chorym..., dz. cyt., s. 59-67.

${ }^{33}$ Por. M. Białecka-Pikul, Dziecko chore w domu. Rodzina w obliczu choroby dziecka, w: Śmierć dziecka a idea domowego hospicjum..., dz. cyt., s. 30-38.
} 
W patologicznych rodzinach przejawia się postawa odtrącenia chorego dziecka, co w wielu przypadkach prowadzi do rozbicia rodziny. Niestety zdarza się też unikanie kontaktu z dzieckiem, czasem nawet wynikające ze współczucia, żalu, które prowadzi do poczucia osamotnienia i utraty bezpieczeństwa przez nie. Domowe hospicjum ma za zadanie umożliwić rodzinie przebywanie wspólne, co wzmacnia więzy rodzinne i umożliwia dziecku czuć się bezpiecznie. Dom jest dla niego najprzyjemniejszym miejscem na ziemi i przebywanie wśród bliskich mu osób jest najrozsądniejszym wyborem, dlatego postawa unikania dziecka, unikania szczerej rozmowy z nim, stawianie mu zbyt wysokich wymagań czy też odtrącanie go przez rodzinę patologiczną podważa sens współpracy takiej rodziny $\mathrm{z}$ domowym hospicjum ${ }^{34}$.

Podobnie, jak w przypadku rodziców, od najbliższej rodziny dziecko terminalnie chore oczekuje akceptacji. Bardzo często rodzeństwo nie potrafi zrozumieć, dlaczego ich siostra, czy brat zachorował, dlaczego to spotkało akurat jedno z nich. Ten brak zrozumienia może powodować skrajne odczucia, od niechęci po nadmierne współczucie. Pomimo choroby mały pacjent hospicjum chciałby być traktowany na równi z rodzeństwem, chciałby się z nimi bawić, być częścią rodziny. Obawa przed chorobą, przed możliwością zrobienia mu przypadkowo krzywdy, może powodować odrzucenie go przez rodzeństwo. Dlatego zadaniem rodziców jest uświadamianie rodzeństwu, że każdy z nich, nawet chory członek rodziny, potrzebuje być traktowany na równi z innymi. Zaakceptowanie go polega na umiejętności traktowania go normalnie, czyli nie użalanie się nad nim, a na udzielaniu mu pomocy i wsparcia, bawieniu się z nim i angażowaniu go w codzienne życie rodziny. Dzięki instytucji domowego hospicjum dla dzieci terminalnie chorzy pacjenci nie muszą żyć z daleka od rodzeństwa. Mogą przebywać z nimi każdego dnia, co umożliwia pełną akceptację $\mathrm{i}$,oswojenie się" $\mathrm{z}$ chorobą ${ }^{35}$.

Niezwykle ważną częścią otoczenia terminalnie chorego dziecka jest zespół pracowników hospicjum domowego. Ponieważ pacjent przebywa większość czasu w domu, zapewnienie mu odpowiedniej opieki medycznej, psychologicznej, pedagogicznej, socjalnej oraz duchowej spoczywa na wykwalifikowanej grupie specjalistów. Do ich obowiązków należy opieka nad pacjentem, leczenie bólu i innych objawów choroby, wspieranie go psychicznie i duchowo. Pediatryczna opieka paliatywna jest jedną z niewielu dziedzin medycyny, w której opieka nad pacjentem ma nie tylko aspekt czysto medyczny ${ }^{36}$. Chore dziecko, przebywające w domu,

\footnotetext{
${ }^{34}$ Por. J. Aldridge, Jak żyć z poważnie chorym..., dz. cyt., s. 10-21.

${ }^{35}$ Por. J. Aldridge, Jak żyć z poważnie chorym..., dz. cyt., s. 31-37.

${ }^{36}$ Por. C. Saunders, Chwila prawdy: opieka nad człowiekiem umierajacym, w: Śmierć i umieranie. Postępowanie z człowiekiem umierającym, red. L. Pearson, Warszawa 1973, s. 63-64.
} 
nie ma zbyt wielu okazji do kontaktu z innymi ludźmi, poza swoją rodziną. Odwiedzający go lekarz, terapeuci, psychologowie, pedagodzy i duchowni powinni traktować pacjenta jak dorosłego człowieka, a zatem szczerze i otwarcie, na ile to możliwe, mówić mu u jego chorobie, o związanych z nią konsekwencjach. Wyrozumiałość, współczucie, okazanie swojej przyjaźni, zwykłych ludzkich gestów pomaga mu radzić sobie $\mathrm{z}$ chorobą. Traktowanie małego człowieka, jako przyjaciela oznacza zaakceptowanie jego ułomności ${ }^{37}$.

\section{Sytuacja rodziny i jej funkcjonowanie w obliczu terminalnej choroby dziecka}

Współczesna psychologia rodzinę traktuje jako system, czyli kompozycję elementów połączonych ze sobą wspólną interakcją. Taka perspektywa sprawia, iż aby zrozumieć zachowanie jednego członka rodziny, należy uwzględnić relacje pomiędzy poszczególnymi jej członkami. Ponieważ w podejściu systemowym rodzina jest jednolitym, zorganizowanym systemem, każda zmiana zachowania jakiegoś członka rodziny ma wpływ na pozostałych ${ }^{38}$. Zatem terminalna choroba dziecka znacząco wpływa na funkcjonowanie rodziny.

Rodzinę, jako system, można rozpatrywać uwzględniając rodzaje granic występujących pomiędzy rodzicami i dziećmi. Według D. Fielda każda rodzina reprezentuje jedną z pięciu typologii:

1. Rodzina chaotyczna, czyli system, który jest prawie pozbawiony więzi pomiędzy jej członkami. W rodzinie takiej przeważają konflikty, dręczenie innych swoimi problemami. System nie zapewnia poczucia bezpieczeństwa, kolektywu, każdy musi sam radzić sobie z problemami. Kierując się emocjami rodzice nie są konsekwentni, w przeważającej większości podejmują błędne decyzje szkodzące swoim dzieciom. Dzieci czują się niekochane, co może prowadzić do rozgoryczenia, a nawet nienawiści i chęci zemsty.

2. Zupełnym przeciwieństwem jest rodzina prawidłowa. System ten cechuje pełna harmonia i współpraca. Rodzice wspólnie wychowują dzieci, równocześnie zapewniając im odpowiednią autonomię w podejmowaniu decyzji. Każdy z członków tej rodziny ma możliwość rozwoju zgodnie z własnymi zainteresowaniami, każdy ma poczucie bezpieczeństwa, akceptacji, ale i każdy ponosi konsekwencje własnych decyzji.

\footnotetext{
${ }^{37}$ Por. C. Saunders, Chwila prawdy..., dz. cyt., s. 64.

${ }^{38}$ Por. M. Braun-Gałkowska, Psychologiczna analiza systemów rodzinnych osób zadowolonych i niezadowolonych z małżeństwa, Lublin 1992, s. 13-18.
} 
3. Rodzina władzy charakteryzuje się pewną, sztywno narzuconą strukturą, w której ojciec lub matka sprawuje władzę i wszystkie decyzje należą do głowy rodziny. Więzy rodzinne i uczucia zostają w tej rodzinie zamienione na polecenia i zadania, z których każdy członek systemu musi się rozliczyć. Nie ma w niej miejsca na pochwały, czułość, natomiast za źle wykonane polecenie należy spodziewać się kary. Cechuje ją przede wszystkim oziębłość, surowość i brak rodzicielskiej miłości.

4. W rodzinie nadopiekuńczej wszystkie poważne problemy są odsuwane na dalszy plan lub zakrywane innymi w celu unikania konfliktów. Rodzice bezgranicznie wierzą swoim dzieciom, starają się im dogodzić w każdy możliwy sposób. Wyręczają je i pomagają we wszystkim, kontrolują ich poczynania i starają się nimi kierować. W rodzinach tego typu unika się karania dzieci, co w przyszłości bardzo utrudnia znoszenie porażek. Bardzo trudno dziecku $\mathrm{z}$ takiej rodziny poradzić sobie w dorosłym życiu, bez wsparcia i ciągłej opieki ze strony najbliższych.

5. Najbardziej trudnym do zdefiniowania jest typ uwikłany. W rodzinie takiej wszystkie relacje są zaburzone, rodzice rezygnują z małżeństwa kosztem zacieśniania relacji z własnymi dziećmi. W tym systemie można zauważyć problem w wyrażaniu emocji, byciu autentycznym, mówieniu otwarcie o swoich problemach. Bardzo często dochodzi do manipulacji, nadużyć, dzieci służą zaspokajaniu potrzeb rodziców ${ }^{39}$.

W stylu demokratycznym dzieci są wychowywane w poszanowaniu swoich uczuć, w atmosferze wzajemnego zaufania i życzliwości. W rodzinie takiej nie stosuje się surowych kar, lecz stara poprzez rozmowę wytłumaczyć błędy swoim podopiecznym. Rodzina taka powinna szybko przystosować się do nowej sytuacji i poradzić sobie $z$ chorobą ${ }^{40}$.

W stylu autokratycznym uczucia zostają zastąpione przez obowiązki i wykonywanie poleceń rodziców. Taka rodzina nie jest zbudowana w poczuciu bezpieczeństwa, zrozumienia. Styl autokratyczny, poprzez zanik relacji międzyludzkich, nie jest przygotowany na tak ciężki cios jak choroba terminalna dziecka. Może to doprowadzić do załamania się osoby kierującej rodziną, ponieważ sytuacja nie może zostać przez nią opanowana i tym samym rodzina może mieć duże trudności z poradzeniem sobie z zaistniałą sytuacją ${ }^{41}$.

\footnotetext{
39 Por. M. Ryś, Systemy rodzinne. Metody badań struktury rodziny pochodzenia i rodziny własnej, Warszawa 2001, s. 10.

${ }^{40}$ Por. M. Ryś, Systemy rodzinne..., dz. cyt., s. 17.

${ }^{41}$ Por. M. Ryś, Systemy rodzinne..., dz. cyt., s. 17.
} 
W rodzinie, w której przeważa styl liberalny, kochający, rodzice bardzo troszczą się o dzieci, jednak rezygnują z stawiania im wymagań i stosowania kar. Powoduje to wychowanie w miłej, kochającej atmosferze, ale bardzo ogranicza umiejętność radzenia sobie w kryzysowych sytuacjach. Dla takiej rodziny choroba terminalna może okazać się zbyt dużym problemem, ponieważ zburzy jej harmonię i spokój. Jeżeli w rodzinie przeważa natomiast styl liberalno-niekochający, atmosfera oziębłości i brak komunikacji są bardzo zauważalne. Rodzice nie troszczą się o potrzeby swoich dzieci, nie okazują im wsparcia ani pomocy. W sytuacji kryzysowej rodzina nie znajdzie oparcia w łączących ją relacjach, a każdy z jej członków będzie starał się poradzić sobie $\operatorname{sam}^{42}$.

Ważnym aspektem dla opiekuńczo-wychowawczego funkcjonowania rodziny są postawy rodzicielskie przyjmowane przez mamę i tatę. Postawy rodzinne można analizować uwzględniając ich stopień nasilenia. W takim podejściu każda skrajność w postępowaniu uznawana jest za niepoprawną, natomiast harmonia i równowaga cechuje rodziny prawidłowo funkcjonujące ${ }^{43}$. M. Braun-Gałkowska wskazała na cztery postawy rodzinne:

1. Bliskość - czyli emocjonalny dystans pomiędzy wszystkimi członkami systemu, jakim jest rodzina. Zarówno nadmierna bliskość, jak i jej brak, można uznać za postawy niepożądane, gdyż uniemożliwiają one poprawne funkcjonowanie systemu.

2. Pomoc - czyli wspieranie się nawzajem w wykonywaniu pewnych zadań, jest niezwykle istotna w przypadku choroby terminalnej. Nadmierna pomoc, czy wręcz wyręczanie, może prowadzić do braku samodzielności i całkowitego uzależnienia się jednej osoby od drugiej, z drugiej strony całkowity brak pomocy prowadzi do poczucia odrzucenia i osamotnienia.

3. Kierowanie-czyli wpływanie na podejmowanie decyzji przez swoje dzieci. Jako młody człowiek dziecko nie zawsze potrafi dokonać odpowiedniego wyboru w swoim życiu, dlatego pomocna rada i wsparcie ze strony najbliższych jest mu potrzebne. Jednak dyrygowanie może spowodować, iż dziecko w przyszłości nie będzie potrafiło samo dokonywać wyborów.

4. Stawianie wymagań - kształtuje charakter człowieka, pozwala mu się rozwijać i poznawać świat. Jednak również w tej postawie skrajności objawiające się brakiem wymagań, bądź oczekiwaniem od dziecka rzeczy, których nie jest w stanie zrobić, mogą powodować frustrację, niechęć, poddanie się bądź rezygnację z dążenia do wymagających celów ${ }^{44}$.

\footnotetext{
${ }^{42}$ Por. M. Ryś, Systemy rodzinne..., dz. cyt., s. 19.

${ }^{43}$ Por. M. Braun-Gałkowska, Metody badania systemu rodzinnego, Lublin 1991, s. 16-17.

${ }^{44}$ Por. M. Braun-Gałkowska, Metody badania systemu rodzinnego..., dz. cyt., s. 17-19.
} 
Rodzina z terminalnie chorym dzieckiem na swojej drodze musi pokonywać każdego dnia wiele przeciwności losu, poczynając od tych na poziomie zabezpieczenia finansowego. Konieczność stałej opieki nad chorym dla większości rodzin wiąże się z porzuceniem przez jedno z rodziców kariery zawodowej, rezygnacją z pracy i oddanie się opiece nad dzieckiem. To rozwiązanie, bardzo często spotykane, powoduje, iż jeden z rodziców zaczyna oddalać się od „życia rodzinnego”. Taka sytuacja może prowadzić do izolacji opiekuna, a razem z nim kolejnych członków rodziny, od reszty społeczeństwa. Rodzicom wydaje się, iż muszą każdą chwilę spędzić ze swoim dzieckiem, aby później nie żałować straconego czasu. Jednak dzięki postępom medycyny chory może przeżyć wiele lat. Spowoduje to kiedyś sytuację, iż po jego odejściu w rodzinie pojawi się pustka, spowodowana całkowitym podporządkowaniem życia jednego z rodziców opiece nad dzieckiem. Również potomek nie będzie mógł opuścić tego świata w spokoju, obawiając się o swoich opiekunów ${ }^{45}$.

Dziecko nie oczekuje od rodziców postawy „męczennika”, osoby cierpiącej dla niego. Postawa cierpiącego, który porzuca swoje plany, swoje życie, aby służyć dziecku, chociaż społecznie aprobowana, może wręcz zaszkodzić małemu pacjentowi. Związane to jest $\mathrm{z}$ tym, iż dobrze rozumie on, że skoro rodzic cierpi, to ono jest winne, bo jego choroba powoduje ten stan. Taki tok rozumowania prowadzi do wyrzutów sumienia u małego pacjenta. Zamiast cieszyć się pozostałym mu czasem, zamartwia się problemami swoich rodziców ${ }^{46}$.

Innym problem związanym z koniecznością porzucenia pracy przez jedno rodziców jest utrzymywanie rodziny przez drugiego małżonka. Pomimo wsparcia udzielanego rodzinie przez hospicjum, zdarzają się przypadki migracji zarobkowej jednego z rodziców. Wysokie bezrobocie zmusza do rozłąki. Rodzina nie ma możliwości spędzania wspólnie zbyt wielu chwil. Może to prowadzić do poczucia zaniedbania bądź niesprawiedliwości przez rodzeństwo. Nie rozumieją oni, dlaczego rodzice nie mają dla nich wystarczająco dużo wolnego czasu. W zależności od wieku i dojrzałości emocjonalnej, rodzeństwo może czuć słabnące więzi w rodzinie, powodowane nie tylko chorobą, ale przede wszystkich czynnościami mającymi na celu walkę $\mathrm{z}$ nią̧${ }^{47}$.

Zbliżając się do dziecka matka oddala się od reszty rodziny. Poprzez zacieśnianie więzi z chorym, osłabia relacje wiążące ją ze zdrowymi dziećmi, które zaczynają czuć się mniej ważne dla niej. Ich problemy schodzą na dalszy plan. Bardzo niekorzystna jest utrata dobrych relacji z mężem. Ponieważ matka staje się najważniejszym opiekunem nieuleczalnie chorego, rola ojca zaczyna sprowadzać

\footnotetext{
${ }^{45}$ Por. J. Aldridge, Jak żyć z poważnie..., dz. cyt., s. 63-64.

${ }^{46}$ Por. J. Aldridge, Jak żý́ z poważnie..., dz. cyt., s. 60-62.

${ }^{47}$ Por. A. Winiarczyk, Migracje zarobkowe jedną z przyczyn niepełności rodziny..., dz. cyt., s. 71-78.
} 
się do osoby odpowiedzialnej za zapewnienie rodzinie bytu materialnego. Dlatego ojciec skupia się na pracy oraz opiece nad pozostałymi dziećmi, podczas gdy matka otacza nad chorym potomkiem „parasol ochronny”. Niestety, parasol ten uniemożliwia ojcu i rodzeństwu opiekę nad nim. Ponieważ matka uważa siebie za jedyną osobę, która potrafi w odpowiedni sposób zająć się nim, ojciec zostaje przez nią całkowicie odrzucony. Zanikają łączące ich relacje. Wszystkie próby zbliżenia się ojca do dziecka mogą spotkać się z krytyką, ponieważ matka uważa siebie za jedyną osobę, przy której czuje się dobrze. Przebywanie z dzieckiem, opieka nad nim, mogą stać się dla niej jedynym celem w życiu. Każda inna czynność, przebywanie $\mathrm{z}$ innymi ludźmi, powoduje u niej poczucie winy z powodu pozostawienia swojego chorego potomka bez należytej opieki ${ }^{48}$.

Może zdarzyć się też sytuacja, że to ojciec stanie się jedynym opiekunem chorego, a matka i rodzeństwo zostaną przez niego odrzucone.

W obydwu sytuacjach może nastąpić rozpad rodziny. Jeżeli małżonkowie nie potrafią okazywać sobie innych uczuć niż gniew i niezrozumienie, ich rodzina może znajdować się w dużym niebezpieczeństwie ${ }^{49}$. Szczególnie narażone na niebezpieczeństwo są rodziny, w których odsunięty na margines ojciec czy matka nie znajdują pomocy z zewnątrz, ze strony specjalistów z dziedziny psychologii. Mogą czuć się niepotrzebni, niedowartościowani, mogą czuć żal. W takiej sytuacji niezwykle mocno cierpi samo chore dziecko. Szczególnie mali pacjenci niepełnosprawni motorycznie, $\mathrm{w}$ większości przypadków mają bardzo dobrze rozwinięty sposób odczuwania emocji, odbierania wszystkich bodźców z otoczenia. Dlatego rozumieją oni dokładnie sytuację, do jakiej doprowadziła ich choroba i jeszcze bardziej cierpią ${ }^{50}$. Większość rodzin, w których pojawiła się nieuleczalna choroba, wymaga wiele pomocy i wsparcia ze strony szerokiej gamy specjalistów. Dzięki wsparciu psychologów można uświadomić rodzicom, jak ważna jest relacja między nimi, sposób w jaki siebie traktują i jak spędzają ze sobą czas wpływa na poczucie szczęścia ich dzieci. Równocześnie pomoc duchowa umożliwia im zrozumienie sensu cierpienia, sensu życia i umiejętność pogodzenia się z losem ${ }^{51}$.

Jeżeli w rodzinie jest więcej niż jedno dziecko, zdrowe dzieci mogą stać się dla rodziców prawie "niewidoczne”. Wynika to przede wszystkim z poczucia, iż choremu najbardziej potrzebna jest pomoc i wsparcie. Pomimo tego, iż są zdrowe, nie mogą zatrzymać swojego dzieciństwa i poczekać, aż rodzice znajdą dla

\footnotetext{
${ }^{48}$ Por. J. Aldridge, Jak żyć z poważnie chorym..., dz. cyt., s. 69-72.

${ }^{49}$ Por. M. Herbert, Kiedy dziecko i jego rodzice potrzebuja pomocy, Gdańsk 2007, s. 19.

${ }^{50}$ Por. M. Białecka-Pikul, Dziecko chore $w$ domu. Rodzina w obliczu choroby dziecka, w: Śmierć dziecka a idea domowego hospicjum..., dz. cyt., s. 36-37.

${ }^{51}$ Por. L. Szczepaniak, Troska o dziecko umierające w szpitalu, Kraków 2008, s. 90-91.
} 
nich trochę czasu. Ich potrzeby uznaje się za mniej ważne tylko $\mathrm{z}$ tego powodu, że nie są śmiertelnie chore. Niestety, ale właśnie taka postawa może prowadzić do zamknięcia się w sobie i poczucia odrzucenia. Zrozumiałe jest, iż dla rodziców szczególnie w przypadku otrzymania złych wiadomości o stanie zdrowia potom$\mathrm{ka}$, problemy pozostałych dzieci w szkole czy w relacjach $\mathrm{z}$ rówieśnikami, mogą wydawać się błahe i nic nieznaczące. Jednak dla nich są to olbrzymie trudności, których bardzo często sami nie są w stanie pokonać. Dziecko nie może zrozumieć, dlaczego to, iż nie jest chore, powoduje, że rodzice nie poświęcają mu swojej uwagi, że jego problemy są ignorowane ${ }^{52}$. Wzbudza to w nim poczucie winy, że swoimi problemami zabiera rodzicom ich cenny czas, który mogliby poświęcić choremu. Wymaga się od nich, aby pomagali w opiece nie otrzymując nic w zamian, aby stali się dorośli w samym środku ich dzieciństwa. Rodzeństwo dobrze rozumie to, iż choroba ich brata czy siostry wymaga od nich zmiany swojego zachowania, rozumieją, że już nie będzie tak beztrosko, ale nie są w stanie zrozumieć, dlaczego stali się mniej ważni dla rodziców. Taka sytuacja powoduje u nich problemy emocjonalne, trudności w nauce, depresję ${ }^{53}$. Niszczy łączące ich relacje zarówno $\mathrm{z}$ rodzicami, jak i z chorym. Ważne, aby rodzice uświadomili im, że są równie ważni, jednak z racji tego, iż chory wymaga pielęgnacji, czas im poświęcany musi zostać ograniczony. Należy wyjaśnić im, kto i kiedy będzie się starał zastępować im rodziców w codziennych obowiązkach. Są to bardzo ważne problemy nurtujące zdrowe rodzeństwo i wyjaśnienie ich powinno być priorytetem. $\mathrm{Z}$ drugiej strony matka i ojciec oczekują od zdrowego rodzeństwa pomocy w opiece i pielęgnacji chorego. Jeżeli liczą na taką pomoc, muszą w zamian sami poświęcić im swój czas i uwagę, aby zdrowe dzieci nie czuły się wykorzystywane ${ }^{54}$.

Sytuacja staje się niezwykle trudna, gdy w rodzinie jest więcej niż jedno chore dziecko. Jeden z rodziców musi zaopiekować się nimi, co może przewyższyć jego siły. Niezwykle pomocne może okazać się w tej sytuacji wsparcie najbliższej rodziny bądź przyjaciół. Częstą dużym wsparciem są dziadkowie. Łączące ich więzy rodzinne oraz olbrzymie doświadczenie życiowe potrafią być bardzo pomocne ${ }^{55}$.

$\mathrm{W}$ przypadku, gdy z różnych przyczyn taka forma pomocy nie jest możliwa, bądź jest niewystarczająca, wsparciem może okazać się wolontariusz. Jako osoba niespokrewniona wnosi do rodziny zupełnie nową formę wsparcia, ponieważ

\footnotetext{
${ }^{52}$ Por. J. Aldridge, Jak żyć z poważnie chorym dzieckiem..., dz. cyt., s. 88.

${ }^{53}$ Por. B. Kędzierska, M. Cynker-McCarthy, Śmierć dziecka i przeżywanie żałoby, w: Pediatryczna opieka paliatywna..., dz. cyt., s. 437.

${ }^{54}$ Por. B. Kędzierska, M. Cynker-McCarthy, Śmierć dziecka i przeżywanie żałoby..., dz. cyt., s. 437.

${ }_{55}$ Por. J. Wawrzyniak, Opiekuńczo-wychowawcza rola dziadków w rodzinie..., dz. cyt., s. 95-103.
} 
pozwala rodzinie poczuć łączność ze społeczeństwem ${ }^{56}$. Wolontariusz staje się dla rodziny przede wszystkim przyjacielem, powiernikiem ich problemów, sekretów. $\mathrm{Z}$ nim przebywająca $\mathrm{w}$ domu matka czy ojciec mogą podzielić się swoimi problemami, emocjami. Ponieważ nie jest pracownikiem hospicjum, a jedynie osobą bezinteresownie niosącą pomoc, którą kieruje przede wszystkim troska o innych, rodzina może traktować go prawie jak część siebie ${ }^{57}$. Pozwala to na bardzo zażyłe relacje, na budowanie mocnych więzi, które pomagają rodzinie przeżywać wszystkie ciężkie chwile ${ }^{58}$. Dzięki wsparciu ze strony wolontariuszy rodzina ma chwilę wolnego czasu, co umożliwia rodzicom odbudowywanie łączących ich relacji oraz umacnianiu uczucia między nimi.

\section{Wsparcie udzielane rodzinie przez najbliższe otoczenie}

W sytuacji terminalnej choroby dziecka rodzina przeżywa początkowo poważny kryzys. Zdaje sobie sprawę, iż sama nie będzie w stanie zapewnić mu odpowiednich warunków do życia i leczenia. $Z$ pomocą przychodzi domowe hospicjum, które umożliwia przebywanie dziecku $\mathrm{w}$ domu, zapewniając mu równocześnie stałą opiekę medyczną ${ }^{59}$. Ponieważ dom jest miejscem, w którym prawie każdy człowiek czuje się bezpiecznie, również chore dziecko, wśród najbliższych, najlepiej znosi ból i cierpienie związane z jego stanem. Jednak pomimo pomocy i wsparcia ze strony specjalistycznego zespołu hospicjum, rodzice bardzo często nie są w stanie sami poradzić sobie z opieką nad chorym $\mathrm{z}$ równoczesnym zapewnieniem bytu rodzinie i opieką oraz wychowaniem reszty rodzeństwa ${ }^{60}$.

$\mathrm{W}$ wielu rodzinach, w których terminalna choroba potomka uniemożliwia jej normalne funkcjonowanie, nieocenione okazuje się wsparcie ze strony dziadków. Podstawową formą pomocy jest ich wychowawczo-socjalizacyjna rola. Jako osoby starsze, z olbrzymim doświadczeniem życiowym, potrafią przekazywać wnukom nie tylko wiedzę ${ }^{61}$. Dzięki zdobytemu doświadczeniu stają się bardzo po-

\footnotetext{
${ }^{56}$ Por. P. Jordan, M. Ochman, Jak pracować z wolontariuszami, Warszawa 20oo, s. 11.

${ }^{57}$ Por. M. Załuska, Społeczne uwarunkowania angażowania się w działalność organizacji pozarządowych, w: Organizacje pozarządowe w społeczeństwie obywatelskim, red. M. Załuska, J. Boczoń, Katowice 1998, s. 95.

${ }^{58}$ Por. G. Nowicki, M. Czekała, Wolontariat w pediatrycznej opiece paliatywnej, w: Pediatryczna opieka paliatywna..., dz. cyt., s. 33-34.

${ }_{59}$ Por. T. Dangel, A. Januszaniec, M. Karwacki, Standardy domowej opieki paliatywnej nad dziećmi, Warszawa 200o, s. 38-45; A. Grudziński, Rola opieki paliatywno-hospicyjnej w pomocy z osobom terminalnie chorym, w: Człowiek wobec bólu, cierpienia i śmierci, red. J. Stala, N. Bravena, Kraków 2013, s. 209.

${ }^{60}$ Por. T. Dangel, A. Januszaniec, M. Karwacki, Standardy domowej opieki paliatywnej nad dziećmi..., dz. cyt., s. $38-45$.

${ }^{61}$ Por. J. Wawrzyniak, Opiekuńczo-wychowawcza rola dziadków w rodzinie..., dz. cyt., s. 95.
} 
mocni w opiece i wychowywaniu wnuków, szczególnie w rodzinie z nieuleczalnie chorym dzieckiem. Ponieważ matka, bądź ojciec, musi poświęcić większość swojego czasu choremu, dziadkowie w tym czasie mogą pomóc w opiece nad rodzeństwem. Szczególnie ważne jest przekazywanie młodszym pokoleniom zasad moralnych, które są podstawą do prawidłowego funkcjonowania w dorosłym życiu. To właśnie od nich wnuki uczą się jak być uczciwym, prawdomównym, jak sumiennie wykonywać swoje obowiązki. Przekazują mu wiarę w Boga, uczą chodzić do Kościoła, odmawiać codzienne modlitwy, tłumaczą, dlaczego tak ważne jest w życiu bycie dobrym człowiekiem ${ }^{62}$. Oczywiście nie można oskarżyć rodziców, że nie wychowują swoich dzieci, ani też, że je zaniedbują, ale w rodzinie, w której tak wiele czasu i uwagi trzeba poświęcić jednemu z rodzeństwa, równocześnie zapewniając rodzinie byt materialny, bardzo trudno jest przeznaczyć wystarczającą ilość czasu, aby nauczyć dzieci wszystkich niezbędnych im do życia zasad moralnych. Najważniejszy jest przykład, jaki swoim zachowaniem dają dzieciom rodzice. Pomimo, iż dziadkowie wychowali już swoje potomstwo i w większości rodzin z nieuleczalnie chorym dzieckiem ich rola sprowadza się bardziej do rozpieszczania niż do wychowywania wnucząt, ciążą na nich znacznie większe obowiązki. Stają się jakby „rodzicami zastępczymi” albo „uzupełniającymi”, ponieważ we współpracy z ojcem i matką zajmują się ich wychowaniem ${ }^{63}$.

Kolejnym niezwykle ważnym aspektem pomocy rodzinie ze strony dziadków jest edukacja wnuków. Z racji swojego wieku oraz doświadczeń życiowych potrafią być wspaniałymi nauczycielami. Ponieważ przeżyli wiele mają do opowiedzenia ciekawe historie, szczególnie związane z ich rodziną oraz ojczyzną. Taka edukacja jest bardzo potrzebna młodym pokoleniom, które coraz częściej zapominają o swoich korzeniach, patriotyzmie. Bardzo ważną cechą, która odróżnia dziadków od rodziców, jest to, iż ci pierwsi nie są odpowiedzialni za wychowanie swoich wnuków, ponieważ obowiązek ten spoczywa na rodzicach. Powoduje to, iż są bardziej wyrozumiali, cierpliwi, potrafią bardziej obiektywnie i wyrozumiale przeanalizować postawy swoich podopiecznych ${ }^{64}$. Również ta cierpliwość powoduje, że mogą być bardzo pomocni w uczeniu dzieci pierwszych kroków, pisania, czytania, w odrabianiu zadań domowych. Wszystkie te czynności edukacyjne, które w sytuacji braku pomocy ze strony dziadków musieliby prowadzić rodzice, bardzo znacząco ich odciążają. Ta pomoc umożliwia rodzicom spędzanie wspólnych

${ }^{62}$ Por. Co zawdzięczamy swoim dziadkom. Komunikat $z$ badań, http://www.cbos.pl/SPISKOM. POL/2001/K_008_01.PDF (01.05.2014).

${ }^{63}$ Por. M. Chmielewska, Rola dziadków w procesie socjalizacji, „Wychowanie na co dzień” (2002) nr 7, s. 17 .

${ }^{64}$ Por. M. Chmielewska, Rola dziadków w procesie socjalizacji..., dz. cyt., s. 17. 
chwil z chorym dzieckiem oraz z sobą nawzajem, co bardzo umacnia łączące ich więzi i scala rodzinę. Okazywana łagodność, wyrozumiałość, cieszenie się z ich postępów edukacyjnych wzmacnia u wnuków poczucie własnej wartości, wzmaga chęć do nauki, rozwijania się. Jest to bardzo pozytywny aspekt przebywania w rodzinie wielopokoleniowej, w ostatnich latach coraz częściej zastępowanej przez model dwupokoleniowy ${ }^{65}$.

Nie tylko edukacja łączy dziadków i ich wnuki. Również ich rola, jako osoby odpowiedzialnej za rozrywkę nie może zostać niedoceniona. Wspólne spacery połączone z niezliczoną ilością pytań, zbieranie grzybów, uprawianie różnego rodzaju sportów, wspólna gra w karty czy inne gry bardzo mocno zacieśniają więzy rodzinne. Pomimo, iż to dziadek, a nie ojciec czy matka, spędzają wolny czas z dzieckiem, mały członek rodziny czuje się kochany, potrzebny, dzięki obcowaniu z nim nie odczuwa tak bardzo ciężaru choroby swojego brata czy siostry. Nie czuje się odrzucony, może się podzielić swoimi problemami i radościami, każdy, nawet najmniejszy jego sukces jest doceniony. Dzięki tej formie pomocy ze strony dziadków, rodzina, pomimo trudności związanych z chorobą dziecka, jego trudnym leczeniem i pielęgnacją, nie oddala się od siebie. Wszyscy pozostają kolektywem, a jedynie zmienia się nieznacznie siła więzi łączących jej członków ${ }^{66}$.

Kolejnym ważnym aspektem pomocy rodzinie oferowanym przez dziadków jest pomoc w opiece i pielęgnacji chorego dziecka. Trudno wyobrazić sobie, jak wyglądałaby opieka nad terminalnie chorym pacjentem domowego hospicjum prowadzona tylko i wyłącznie przez matkę bądź ojca, bez wsparcia. Jeden człowiek miałby ogromne trudności żeby przez wiele miesięcy, a niejednokrotnie i lat, być $\mathrm{w}$ stałym pogotowiu i cały swój czas poświęcać na pracę z dziećmi i opiekę nad chorym. W dłuższej perspektywie czasu prowadziłoby to do wycieńczenia organizmu, frustracji, a może i depresji, wyobcowania w społeczeństwie. Dlatego dziadkowie, którzy wspierają w opiece i pielęgnacji są nieocenioną pomocą. To oni karmią, pielęgnują, noszą na rękach bądź wożą wózkiem chore dziecko. Przekazują mu miłość, współczucie, ale równocześnie umożliwiają mu, w miarę jego możliwości, decydowania o swoim życiu. W przeciwieństwie do rodziców, nie planują dziecku przyszłości, tylko razem z nim cieszą się każdą chwilą, jaka została im dana. Dzięki nim czuje się cały czas kochane, potrzebne. Rodzice mogą natomiast zająć się pozostałymi dziećmi, aby i one czuły się ważne i kochane. Taka wymienność obowiązków w opiece na chorym i zdrowym rodzeństwem pozwala rodzicom odpocząć, zregenerować siły. Dzięki niej czują, że nie zostali sami ze swoimi problemami, że zawsze mogą na kogoś liczyć. Niezwykle potrzebna jest

\footnotetext{
${ }^{65}$ Por. J. Wawrzyniak, Opiekuńczo-wychowawcza rola dziadków w rodzinie..., dz. cyt., s. 96-98.

${ }^{66}$ Por. Z. Włodowska, O późnej miłości, „Wychowanie na co dzień” (1995) nr 2, s. 22-23.
} 
świadomość, że w każdej, nawet najgorszej chwili, rodzina nie zostanie sama, że niezależnie od okoliczności, będzie można liczyć na wsparcie dziadków. Taka postawa zapewnia poczucie bezpieczeństwa nie tylko rodzicom, ale i ich dzieciom, które rozumieją, że nawet, jeżeli rodzice nie będą mogli im pomóc, zawsze mogą udać się do dziadków, którzy na pewno znajdą chwilę czasu, aby wspólnie z wnukami rozwiązać ich problemy bądź cieszyć się $\mathrm{z}$ ich sukcesów ${ }^{67}$.

Nie tylko dziadkowie pomagają rodzinie w zmaganiu się z chorobą dziecka. Jest wiele osób, których pomoc może służyć wsparciu rodziny. Niewątpliwie do takich ludzi można zaliczyć przyjaciół i najbliższą rodzinę $e^{68}$. Są to ludzie gotowi poświęcić bezinteresownie swój czas, aby umożliwić rodzinie normalne funkcjonowanie. Nieocenioną pomocą świadczoną przez przyjaciół jest możliwość rozmowy z osobą niebędącą częścią rodziny. Dzięki takiej rozmowie ojciec czy matka ma możliwość otwarcia się przed przyjacielem, opowiedzenia mu o swoich problemach, wątpliwościach, o wszystkim, z czym nie może sobie poradzić. W wielu przypadkach rodzic nie oczekuje rady od przyjaciela. Oczekuje wysłuchania i zrozumienia. Ponieważ choroba dziecka i związane z nią poczucie krzywdy i niesprawiedliwości są bardzo trudne do zniesienia, rozmowa z przyjacielem umożliwia niejako „zrzucenie tego ciężaru ze swoich barków”. Ale nie tylko rozmowa jest pomocna rodzinie. Również pomoc w codziennych obowiązkach bardzo ułatwia normalne funkcjonowanie. Bardzo cenne i potrzebne jest też zajmowanie się pozostałymi dziećmi, aby nie czuły się zaniedbane. Rozmowa i zabawa z nimi, pomoc w odrabianiu lekcji, czy nawet wysłuchanie ich bardzo odciążą rodziców i dziadków ${ }^{69}$.

Zarówno dziadkowie, jak i przyjaciele są niezwykle ważni dla funkcjonowania rodziny z dzieckiem terminalnie chorym. Niezależnie od formy świadczonej przez nich pomocy, umożliwiają rodzinie pozostanie kolektywem. Dzięki ich wsparciu każdy członek rodziny czuje, że zawsze może liczyć na czyjeś wsparcie i dzięki nim każdy w rodzinie czuje się bezpiecznie ${ }^{70}$.

Funkcjonowanie rodziny jako systemu uzależnione jest od wielu czynników, które mogą wpływać integrująco jak i negatywnie na atmosferę życia rodzinnego. Bez wątpienia śmiertelna choroba dziecka, staje się wyzwaniem dla wszystkich elementów systemu. Cyrkularność życia rodzinnego oraz dążenie do utrzymania wewnętrznej równowagi powoduje bezpośrednie wpływanie poszczególnych członków rodziny na siebie. Zachowanie rodziców oddziałuje zarówno na chorego

\footnotetext{
${ }^{67}$ Por. Z. Włodowska, O późnej miłości..., dz. cyt., s. 22-23.

${ }^{68}$ Por. M. Świderska, Pomoc świadczona rodzinie wychowującej dziecko niepełnosprawne..., dz. cyt., s. $43-44$.

${ }^{69}$ Por. M. Świderska, Pomoc świadczona rodzinie wychowującej dziecko niepełnosprawne..., dz. cyt., s. $43-44$.

${ }^{70}$ Por. M. Świderska, Pomoc świadczona rodzinie wychowującej dziecko niepełnosprawne..., dz. cyt., s. 12.
} 
jak i na zdrowe rodzeństwo. Choroba, może stać się zarówno przyczyną dezintegracji oraz konfliktów w rodzinie bądź też wyzwaniem, które wzmocni cały system rodzinny oraz sprawi, że nawet w obliczu śmierci, w okresie żałoby, rodzice, rodzeństwo oraz dziadkowie będą umieli stopniowo z czasem powrócić do normalnego funkcjonowanie. Istotnym jest, iż rodzina dziecka terminalnie chorego, która znajduje się pod opieką hospicjum domowego, może liczyć na szeroko definiowane wsparcie specjalistów, którzy pozwolą odzyskać „wewnętrzny spokój” po starcie potomka.

\section{Proponowana literatura}

Aldridge J., Jak żyć z poważnie chorym dzieckiem, Kraków 2008.

Białecka-Pikul M., Dziecko chore w domu. Rodzina w obliczu choroby dziecka, w:Śmierć dziecka a idea domowego hospicjum dla dzieci, red. M. Szczerbińska-Polak, Kraków 2005.

Biniak R., Opieka duchowna nad umierajacymi, w: Opieka Paliatywna, red. M. Krajnik, M. Rogiewicz, Bydgoszcz 1998.

Binnebesel J., Krakowiak P., Modlińska A., Podręcznik koordynatora wolontariatu hospicyjnego, Gdańsk 2008.

Braun-Gałkowska M., Metody badania systemu rodzinnego, Lublin 1991.

Braun-Gałkowska M., Psychologiczna analiza systemów rodzinnych osób zadowolonych i niezadowolonych z małżeństwa, Lublin 1992.

Chmielewska M., Rola dziadków w procesie socjalizacji, „Wychowanie na co dzień” (2002) $\mathrm{nr} 7$.

Co zawdzięczamy swoim dziadkom. Komunikat z badań, http://www.cbos.pl/SPISKOM. POL/2001/K_008_01.PDF (01.05.2014).

Dąbrowski Z., Pedagogika opiekuńcza w zarysie, Olsztyn 2006.

Dangel T., Januszaniec A., Karwacki M., Standardy domowej opieki paliatywnej nad dziećmi, Warszawa 2000.

de Walden-Gałuszko K., Psychospołeczne aspekty opieki paliatywnej, w:Podstawy opieki paliatywnej, red. K. de Walden-Gałuszko, Warszawa 2006.

Grudziński A., Rola opieki paliatywno-hospicyjnej w pomocy z osobom terminalnie chorym, w: Człowiek wobec bólu, cierpienia i śmierci, red. J. Stala, N. Bravena, Kraków 2013.

Herbert M., Kiedy dziecko i jego rodzice potrzebuja pomocy, Gdańsk 2007.

Hinds P. S., Oakes L.L., Hicks J., End-of-life care for children and adolescents, „Semin. Oncol. Nurs" 21 (2005) nr 1.

Hołubicki M., Opieka paliatywna i hospicyjna w Polsce, w:Leczenie bólu nowotworowego i opieka paliatywna nad dziećmi, red. B. Block, W. Otrębski, Lublin 1997.

Jan Paweł II, Chorzy na raka wołaja o pomoc. Przemówienie do Międzynarodowego Towarzystwa Onkologii Ginekologicznej z dnia 30 września 1999r. 
Jarosz J., Hilgier M., Zasady diagnostyki i leczenia bólu, w: Podstawy opieki paliatywnej, red. K. de Walden-Gałuszko, Warszawa 2006.

Jordan P., Ochman M., Jak pracować z wolontariuszami, Warszawa 2000.

Kędzierska B., Cynker-McCarthy M., Śmierć dziecka i przeżywanie żałoby, w:Pediatryczna opieka paliatywna, red. A. Korzeniewska-Eksterowicz, W. Młynarski, Łódź 2011.

Kozłowska I., Pietruk K., Ból dziecka a ból osoby dorosłej. Postrzeganie bólu i cierpienia przez personel pracujacy w hospicjum dla dzieci i dla dorostych, w:W drodze do brzegu życia,tom VII, red. E. Krajewska-Kułak, C. Łukaszuk, Białystok 2009.

Kromolicka B., Wolontariusz w życiu społecznym, w: W kręu humanistycznej edukacji, red. J. Brągiel, Z. Jasiński, Opole 2000.

Kromolicka B., Wolontariat nadzieja na lepsze jutro, w: Wolontariat w życiu społecznym środowiska lokalnego, red. B. Kromolicka, Szczecin 2003.

Kuleta M., Doświadczanie żalu po stracie w perspektywie społeczno-kulturowej. Znaczenie rytuałów żałobnych, w:Zdrowie, stres, choroba w wymiarze psychologicznym, red. H. Wrona-Polańska, Kraków 2008.

Myśli Korczaka, http://2012korczak.pl/ (o1.05.2013).

Nowicki G., Czekała M., Wolontariat w pediatrycznej opiece paliatywnej, w: Pediatryczna opieka paliatywna, red. A. Korzeniewska-Eksterowicz, W. Młynarski, Łódź 2011.

Olechnowicz H., Dziecko własnym terapeuta, Warszawa 2006.

Przysło Ł., Fenomenologia, neurobiologia, diagnostyka i leczenie bólu w pediatrii, w:Pediatryczna opieka paliatywna, red. A. Korzeniewska-Eksterowicz, W. Młynarski, Łódź 2011.

Ryś M., Systemy rodzinne. Metody badań struktury rodziny pochodzenia i rodziny własnej, Warszawa 2001.

Ryżanowska D., Dziecko wobec cierpienia, w: Psychologia zdrowia dzieci i młodzieży, red. W. Pilecka, Kraków 2011.

Salij J., Człowiek umierający jako bliźni, w: Sztuka rozmowy z chorym, red. B. de Barbaro, Kraków 2001.

Saunders C., Hospicjum Św. Krzysztofa, w: Sens choroby, sens śmierci, sens życia, red. H. Bortnowska, Kraków 1980.

Saunders C., Chwila prawdy: opieka nad człowiekiem umierającym, w: Śmierć i umieranie. Postępowanie z człowiekiem umierającym, red. L. Pearson, Warszawa 1973.

Szamborska A., Pietruk K., Człowiek hospicjum, czyli model wolontariatu w opiece paliatywnej, w: W drodze do brzegu życia, tom VII, red. E. Krajewskaj-Kułak, C. Łukaszuk, Białystok 2009.

Świderska M., Pomoc świadczona rodzinie wychowującej dziecko niepetnosprawne, „Pedagogika rodziny" (2011) $\mathrm{nr}$ 1(2).

Szczepaniak L., Troska o dziecko umierajace w szpitalu, Kraków 2008.

Tobiasz-Adamczyk B., Szafraniec K., Bajka J., Zachowania w chorobie. Opis przebiegu choroby z perspektywy pacjenta, Kraków 1999. 
Tokarski S., Kierowanie ludźmi, Koszalin 1997.

Tryjarska B., Systemowa-komunikacyjna terapia rodzin, w: Psychoterapia. Praktyka-podręcznik akademicki, red. L. Grzesiuk, Warszawa 2006.

Wawrzyniak J., Opiekuńczo-wychowawcza rola dziadków w rodzinie, „Pedagogika rodziny"(2011) nr 1(2).

Winiarczyk A., Migracje zarobkowe jedna z przyczyn niepetności rodziny, „Pedagogika rodziny" (2011) $\mathrm{nr} 1(2)$.

Włodowska Z., O późnej miłości, „Wychowanie na co dzień” (1995) nr 2.

Wójcik R., Rodzaje bólu nowotworowego u dzieci, w: Leczenie bólu nowotworowego i opieka paliatywna nad dziećmi, red. T. Dangel, Warszawa 2001.

Wrona-Polańska H., Psychologiczne aspekty informowania pacjentów o chorobie, w:Zmagając się z choroba nowotworową. Psychologia współczesna wobec pacjentów onkologicznych, red. D. Kubacka-Jasiecka, W. Łosiak, Kraków 1999.

Załuska M., Społeczne uwarunkowania angażowania się $w$ działalność organizacji pozarządowych, w: Organizacje pozarządowe w społeczeństwie obywatelskim, red. M. Załuska, J. Boczoń, Katowice 1998. 